\title{
Farmers' motivation to produce kopyor coconut: a case in Ngagel Village, Pati Regency
}

\author{
Zuhud Rozaki ${ }^{1, *}$, Alvin Mahardina ${ }^{1}$, Mohd Fauzi Kamarudin ${ }^{2}$, Muhamad Aziz \\ Proklamalatu ${ }^{3}$, and Sri Sari Utami ${ }^{4}$ \\ ${ }^{1}$ Department of Agribusiness, Universitas Muhammadiyah Yogyakarta, 55183 Jalan \\ Brawijaya, Kasihan, Bantul, Yogyakarta, Indonesia \\ ${ }^{2}$ Universiti Teknikal Malaysia Melaka, Jalan Hang Tuah Jaya, 76100 Durian Tunggal, \\ Melaka, Malaysia \\ ${ }^{3}$ Universitas Sebelas Maret, Jl. Ir. Sutami No.36,Kota Surakarta, Central Java, Indonesia \\ ${ }^{4}$ Akademi Pertanian Yogyakarta, Jalan Palagan Tentara Pelajar Km. 7, Sleman, Yogyakarta \\ 55581, Indonesia
}

\begin{abstract}
The national market demand for Kopyor coconut is increasing. However, this increase in demand is not matched with sufficient supply. This study aims to determine and describe the farmers' motivation in producing Kopyor coconut in Ngagel Village, Pati Regency. The research method used is descriptive. 40 respondents were interviewed using semi-structured questionnaires. Likert scale and Rank Spearman were used to analyse the data. The findings of the study show that the farmers' motivations to produce Kopyor coconut are in medium score which mainly focus on fulfilling physiologic needs. The farmers' motivation to produce Kopyor coconut should be supported and increased as this agriculture product has potency for supporting the farmers economics.
\end{abstract}

\section{Introduction}

Indonesia has the potential to develop the plantation commodities such as cocoa, rubber, palm, coffee, sago, tea and coconut [1]. The role of the agriculture, including plantation, sector to Indonesia GDP is big about $10 \%$. In the current Covid-19 pandemic condition this sector has strategically contributed to the country's economy through the export of plantation products[2]. As a commodity, coconut is suitable to be planted in many areas in Indonesia.

Coconut can be processed into many kinds of products. People use coconut milk and meat for many processed food, besides drinking the coconut water [3]. In some areas of Indonesia, this product is developed as potential commodity. Developing coconut as a

*Corresponding author : zaki@umy.ac.id 
potential commodity in particular area is important as a strategy to boost farmers economy [4-6].

One coconut type that is being produced and gaining popularity among Indonesian is Kopyor coconut. Unlike other coconuts, this coconut is popular as a drink. The coconut has the characteristics that the meat is not firm and not attached to the shell. Kopyor is also known as the natural mutant coconut. People like the taste even though the price is quite expensive as compared to the normal coconut. Due to its popularity and high demand, Kopyor the supply of Kopyor is not easy to be found. As such, this commodity is worth to be developed.

Pati Regency is one of Kopyor producer in Central Java Province with a production of $1,030,757$ tonnes in 2020 [7]. In adjacent, Ngagel Village is contributing to this production. Many farmers are producing Kopyor to fulfil the demand. Despite this, the high supply demand has yet to be met reflecting the the potency of this coconut type. In this aspect, the motivation of farmers to continue to produce Kopyor is interesting to be studied. This is because the farmers motivation to still produce agriculture products is important as it effects their will and motivation to do farming [8,9]. This study aims to analyse the motivation of farmers to produce Kopyor in Ngagel Village, of the Pati Regency.

\section{Research Method}

The study used descriptive method to describe the findings. This study was conducted in Ngagel Village, Pati Regency, Central Java. 40 Kopyor farmers were randomly selected as respondents. To collect primary data, the respondents were interviewed using semistructured questionnaires. Maslow Theory of Motivation was used to arrange the variables and indicator regarding the farmers motivation on producing Kopyor. The motivation consists of four main variables: physiologic needs, security needs, social needs and achievement needs. All indicators are measured with Likert scale: Disagree (1), Neutral (2), Agree (3) (Table 1). Rank Spearman analysis is used to analyse factors that affects motivation. Demographic of the respondents become the independent variable and motivation is the dependent variable. Table 1 below describes the motivation variables and indicators.

Table 1. Motivation Variables and Indicators

\begin{tabular}{|c|l|}
\hline Variable & \\
\hline \multirow{4}{*}{ Physiologic } & Fulfil family food needs \\
\cline { 2 - 2 } & Fulfil family clothes needs \\
\cline { 2 - 2 } & Fulfil family residence \\
\cline { 2 - 2 } & Fulfil children education \\
\cline { 2 - 2 } Security & Fulfil family health \\
\cline { 2 - 2 } & Saving \\
\cline { 2 - 2 } Social & Investation \\
\cline { 2 - 2 } & Social interaction with other farmers \\
\cline { 2 - 2 } & Open cooperation with other farmers \\
\hline Achievement & Relp other Kopyor coconut farmer to develop their farming \\
\cline { 2 - 2 } & $\begin{array}{l}\text { Recognition from others regarding the abilities in Kopyor coconut } \\
\text { farming }\end{array}$ \\
\hline
\end{tabular}

Measurement: Disagree (1), Neutral (2), Agree (3) 


\section{Results and Discussion}

\subsection{Demographics of respondents}

The data shows that Kopyor farmers have special characteristics in relation to their demographics. Among all the respondents, the age range of $42-55$ dominates with $52.5 \%$. This is followed by 56-69 years old and $28-41$ years old, with $40.0 \%$ and $3 \%$ respectively. The study further found that the productive age farmers $(42-55$ and $28-41)$ are the majority. However, the ageing farmers $(56-69)$ with a total population of $40 \%$ of the total population show current general problem in agriculture [10]. Other problem in Kopyor farming is the limited land for production as mentioned in previous study [11]. The farmers education is generally low such as only reaching the elementary school level. Nevertheless, in the case of this study, the respondents show quite a good education background. $40 \%$ attained the level of senior high school and 7.5\% attained the elementary school level. . Previous studies have shown that farmers with good education will response positively with new innovations. This is the case with the Kopyor farmers [12,13].

With Kopyor having good price in the market and good production, this is seen to assist towards increase of the farmers income. This study shows that the Kopyor farmers income are mostly more than IDR 2,000,000. per month. This is a good amount for farmers in Indonesia whereby many other farmers can only get lesser income than that. In this aspect, Indonesia needs to provide more support to boost farmers income [2,14]. Additionally, long experience in Kopyor farming will contribute to more abilities and good decision making regarding Kopyor farming. This study shows that the respondents with 2-15 years of experience is $35 \%$. The rest $(65 \%)$ have 16 to 43 years of experience. Table 2 below illustrates the demographic of the respondents.

Table 2. Demographic of Respondents

\begin{tabular}{|l|r|r|r|r|r|}
\hline & \multicolumn{1}{|c|}{ Freq. } & Percentage & \multicolumn{2}{|c|}{ Freq. } & Percentage \\
\hline Age (Year) & \multicolumn{3}{|c|}{ Income (IDR) } \\
\hline $28-41$ & 21 & 7.5 & $700,000-2,466,667$ & 11 & 27.5 \\
\hline $42-55$ & 16 & 42.5 & $2,466,668-4,233,335$ & 23 & 57.5 \\
\hline $56-69$ & 40 & 100.0 & $4,233,336-6,000,000$ & 6 & 15.0 \\
\hline Total & & & Total & 40 & 100.0 \\
\hline Education & 7 & 17.5 & \multicolumn{3}{|c|}{ Farming Experience (Year) } \\
\hline $\begin{array}{l}\text { Elementary } \\
\text { School }\end{array}$ & 16 & 20.0 & $2-15$ & 14 & 35.0 \\
\hline Primary School & 9 & 40.0 & $16-29$ & 17 & 42.5 \\
\hline $\begin{array}{l}\text { Senior High } \\
\text { School }\end{array}$ & 40 & 100.0 & $30-43$ & 9 & 22.5 \\
\hline University & & & Total & 40 & 100.0 \\
\hline Total & & & & \\
\hline
\end{tabular}

\subsection{Motivation}

Motivation towards innovation, or particular activities or program varies among people. Studies have used Maslow hierarchy motivation to analyse the motivation degree. In this study, Maslow hierarchy motivation is used to analyse the farmers motivation on producing 
Kopyor. The result of the study shows that motivation for physiologic needs shows a high score, where Kopyor farming becomes the source for farmers to fulfil their daily needs such as food, clothes and residence for their family. Social and self-actualization shows a medium score, and achievement shows a low score. These results show that the motivation of farmers to produce Kopyor is not high enough. As such, this needs to be more supported in order to increase the famers motivation. This is because the potency of Kopyor is high, proven by inability to fulfil the high Kopyor supply demand. Table 3 below illustrates the farmers motivation.

Table 3. Farmers Motivation

\begin{tabular}{|l|r|r|c|}
\hline \multicolumn{1}{|c|}{ Variable } & \multicolumn{1}{c|}{ Score Range } & \multicolumn{1}{c|}{ Total Score } & Category \\
\hline Physiologic & $5.0-15$ & 13.88 & High \\
\hline Security & $2.0-6.0$ & 2.60 & Low \\
\hline Social & $3.0-9.0$ & 5.55 & Medium \\
\hline Achievement & $2.0-6.0$ & 2.86 & Low \\
\hline Self-Actualization & $2.0-6.0$ & 4.60 & Medium \\
\hline Total & $\mathbf{1 4 - 4 2}$ & $\mathbf{2 9 . 4 9}$ & Medium \\
\hline
\end{tabular}

\subsection{Factors affecting motivation}

First, it was found that demographic respondents such as age, education, income and farming experience in general tend to have effect to the people's response, attitude and motivation $[15,16]$. In adjacent, age in all motivation variables don't show any significant correlation. In this aspect, young or old farmer will likely to have the same motivation. Secondly, education is found to have significant correlation with physiologic need, where the point is negative. This shows that higher education will more likely to have low physiologic variables. Education is also found to have positive significant correlation with security and social needs, as the higher the education, the more it will affect the increase for security and social needs.

Table 4. Factors Affecting Motivation

\begin{tabular}{|l|l|r|r|r|c|c|}
\hline \multicolumn{2}{|l|}{} & Physiologic & Security & Social & Achievement & $\begin{array}{c}\text { Self- } \\
\text { Actualization }\end{array}$ \\
\hline Age & Rs & 0.101 & -0.078 & -0.189 & -0.120 & -0.117 \\
\hline & Sig. & 0.534 & 0.633 & 0.243 & 0.460 & 0.472 \\
\hline Education & Rs & $-0.486^{* *}$ & $0.309^{*}$ & $0.358^{*}$ & 0.114 & -0.142 \\
\hline & Sig. & 0.001 & 0.04 & 0.02 & 0.485 & 0.383 \\
\hline Income & Rs & $-0.409^{* *}$ & -0.007 & -0.003 & 0.200 & 0.257 \\
\hline $\begin{array}{l}\text { Farming } \\
\text { Experience }\end{array}$ & Sig. & 0.009 & 0.964 & 0.988 & 0.215 & 0.110 \\
\hline & Rs & $0.272^{*}$ & -0.070 & 0.009 & -0.231 & -0.176 \\
\hline
\end{tabular}

Third, income is found to have significant correlation with physiologic need with negative point. This shows that the higher the income will more likely decrease the physiologic needs. Last but not least, farming experience has significant correlation with physiologic need with positive point. This means that the longer farming experience a 
farmer has, the physiologic need will likely to be higher too. Table 4 below presents the factors affecting motivation.

\section{Conclusion and Recommendation}

Kopyor coconut is an agriculture product that has potency to be developed. The demand is high, but the supply has yet to be met. This study found that the farmers' motivation in Ngagel Village is in medium score. This can be improved further to increase the production and sustainability of Kopyor supply. Additionally, age doesn't have any significant correlation with motivation variable which shows that anybody can try to produce Kopyor because it can be their motivation. More attention regarding Kopyor production is needed to improve the supply of this product to meet the high market demand, and support the farmers economy.

Acknowledgement. The authors would like to express huge gratitude to Universitas Muhammadiyah Yogyakarta for supporting this study. Credit also goes to Universiti Teknikal Malaysia Melaka for the opportunity for this academic collaboration.

\section{References}

1. K. Endra, Faktor-Faktor Yang Mempengaruhi Kinerja Keuangan Pada Perusahaan Perkebunan Yang Terdaftar Di Bursa Efek Indonesia Periode 2012-2016., Universitas Islam Riau, 2018.

2. Z. Rozaki, COVID-19, Agriculture, and Food Security in Indonesia, Rev. Agric. Sci. 8, 243 (2020).

3. W. Rahman, J. Magos Brehm, and N. Maxted, ). Setting conservation priorities for the wild relatives of food crops in Indonesia. Genetic Resources and Crop Evolution, Genet. Resour. Crop Evol. 66, 809 (2019).

4. Z. Rozaki, O. Wijaya, and C. K. Wardana, Agriculture developement based on regional potency in kulonprogro regency, IOP Conf. Ser. Earth Environ. Sci. 683, (2021).

5. M. K. Hasan, T. S. T. Tanaka, M. M. Alam, M. R. Ali, and C. K. Saha, Impact of modern rice harvesting practices over traditional ones, Rev. Agric. Sci. 8, 89 (2020).

6. N. R. Timisela, M. Masyhuri, and D. H. Darwanto, Development Strategy of Sago Local Food Agroindustry Using Analytical Hierarchy Process Method, Agraris: J. Agribus. Rural Dev. Res. 7, 36 (2021).

7. M. Asa, Nikmat Lezat Kelapa Kopyor. Trans 7 Official. (2016).

8. I. J. Jambo, J. C. J. Groot, K. Descheemaeker, M. Bekunda, and P. Tittonell, Motivations for the use of sustainable intensification practices among smallholder farmers in Tanzania and Malawi, NJAS - Wageningen J. Life Sci. 89, 100306 (2019).

9. R. P. Widiani Priswita, S. Anantanyu, Komariah, and M. S. Budiastuti, Potential of Ratoon Rice Farming Development in Central Java Province, Indonesia for Climate Change Adaptation and Mitigation, IOP Conf. Ser. Earth Environ. Sci. 549, (2020).

10. P. Saiyut, I. Bunyasiri, P. Sirisupluxana, and I. Mahathanaseth, Changing age structure and input substitutability in the Thai agricultural sector, Kasetsart J. Soc. Sci. 38, 259 (2017).

11. Z. Rozaki, Decrease of agricultural land and industry growth in Special Region of Yogyakart, IOP Conf. Ser. Earth Environ. (2020). 
12. Z. Rozaki, D. I. Salassa, and R. B. Nugroho, Farmers' responses to organic rice farming in Indonesia: Findings from central Java and south Sulawesi, Open Agric. 5, 703 (2020).

13. P. Peltonen-Sainio, J. Sorvali, and J. Kaseva, Winds of change for farmers: Matches and mismatches between experiences, views and the intention to act, Clim. Risk Manag. 27, 100205 (2020).

14. A. Devaux, P. Kromann, and O. Ortiz, Potatoes for Sustainable Global Food Security, Potato Res. 57, 185 (2014).

15. L. R. Levis, K. Sukesi, S. Sugiyanto, and Y. Yuliati, Farmers behaviour regarding food security by practicing the "salome" farming system as local wisdom in west timor, east nusa tenggara province, indonesia, Trop. Subtrop. Agroecosystems 20, 231 (2017).

16. B. Winarno, Neoliberal Policy of Indonesia's Agricultural Revitalization. Jurnal Hubungan Internasional. 5, 31 (2016). 